\title{
The Effect of Work-Family Conflict and Balancing Strategy towards Wive's Job Satisfaction
}

\author{
Euis Sunarti $^{1 *}$, Risda Rizkillah ${ }^{2}$, Novy Tri Muktiyah ${ }^{3}$ \\ ${ }^{1,2,3}$ Department of Family and Consumer Sciences, Faculty of Human Ecology, IPB University, \\ Bogor 16680, West Java, Indonesia \\ *) Corresponding author: euisnm@gmail.com
}

\begin{abstract}
This study aims to analyze the effects of work-family conflicts and balancing strategies on job satisfaction felt by families in working husbands and wives. The design of this study was crosssectional with a sample of 160 wives in families with working wives who have children aged 09 years chosen stratified non-proportional random sampling in West Bogor and Central Bogor District, Bogor City. The data collection process carried out using a questionnaire. This study's results indicate that there is a significant negative correlation between work-family conflict and job satisfaction. Besides, theBesidesnificant positive correlation between the strategy of balancing family and work with job satisfaction. Based on the results of the regression test, the data show that work-family conflict and the balancing strategy have an effect on job satisfaction 22.2 percent, and the rest is influenced by other variables not examined. The implications of these results require a broader study for the elaboration of wives' job satisfaction factors.
\end{abstract}

Keywords: balancing strategy, wives' job satisfaction, work-family conflict

\begin{abstract}
Abstrak
Penelitian ini bertujuan untuk menganalisis pengaruh antara konflik kerja-keluarga dan strategi penyeimbangan terhadap kepuasan kerja yang dirasakan oleh istri pada keluarga dengan suami istri bekerja. Desain dari penelitian ini adalah cross-sectional dengan total contoh sebanyak 160 istri pada keluarga dengan suami istri bekerja yang memilki anak usia 0-9 tahun yang dipilih secara stratified nonproportional random sampling di Kecamatan Bogor Barat dan Bogor Tengah, Kota Bogor. Proses pengambilan data dilakukan dengan menggunakan kuesioner. Hasil penelitian ini menunjukkan bahwa terdapat hubungan yang signifikan negatif antara konflik kerja-keluarga dengan kepuasan kerja. Selain itu, terdapat hubungan yang signifikan positif antara strategi penyeimbangan kerja keluarga dengan kepuasan kerja. Berdasarkan hasil uji regresi, data menunjukkan bahwa konflik kerja-keluarga dan strategi penyeimbangan memiliki pengaruh terhadap kepuasan kerja sebesar 22,2 persen dan sisanya dipengaruhi oleh variabel lain yang tidak diteliti. Implikasi dari hasil tersebut adalah diperlukan kajian yang lebih luas untuk elaborasi faktor kepuasan kerja istri.
\end{abstract}

Kata kunci : kepuasan kerja istri, konflik kerja-keluarga, strategi penyeimbangan 


\section{Introduction}

The increased participation of women in the public sector is caused by increasing family needs, thus causing wives to make a living outside the home. However, some wives work outside the home because they want to actualize themselves due to increased education, access, opportunities, and desires for high social needs (Christine et al., 2010). The Central Statistics Agency (BPS) divides the types of jobs into two types: formal job and informal job. Formal jobs include the business category assisted by permanent laborers/employees category, while the rest are informal (BPS, 2012). Based on the allocation of working time, workers in the private sector have set working hours in law No. 13 of 2003 concerning Manpower, particularly articles 77 through 85. In Article 77, paragraph 1, Law No. 13 of 2003, stated that every employer is obliged to implement the provisions of working hours. These working hours conditions regulated in two systems. Both systems are for employees who work six days a week, and working hours are 7 hours a day, while for employees with five working days a week, their work obligations are 8 hours a day.

The existence of a dual role performed by the wives gives its problems to the wives, especially in families who still have baby, preschool, and school-aged children. Due to the role of the wives in public and the domestic sector requires time, attention, and energy. The wives who decide to work outside the home will provide difficulties in the division of tasks in the household and child care. The wives who work outside the home can not leave their role as housewives and in terms of childcare Ollenburg and Moore (in Tambingon, 1999). In line with this, according to Stoner and Wankel (1986), the inclusion of wives in the public sector presents its problems because of the dual roles it must face

Someone unable to integrate work-family interests tends to experience tension or conflict (Hatta, 2011). There are two types of work-family conflicts: work conflicts affect families, and family conflicts affect work (Netemeyer, Boles, \& McMurrian, 1996). The emergence of problems and conflicts both at work and family requires that women who have a dual role can manage the balance between work-family well so that they can minimize the occurrence of work-family conflict. Work-family conflict experienced by the wives can reduce by carrying out work-family balancing strategies using coping strategies. A work-family balancing strategy is needed so that the wives can fulfill the role both in the family and work. A good work-family balancing strategy can minimize the occurrence of family-work conflicts that impact the achievement of job satisfaction felt by the wives. Conversely, a wife who does not have an excellent work-family balancing strategy will increase work-family conflict, thereby impacting job satisfaction.

Meintier et al. (2011) stated that heavy workloads only affect the wives in her life, which can lead to fatigue, which will ultimately result in low life satisfaction. Many demands that the wives receive from the public and domestic sectors and their ability to fulfill their family duties and the achievements received in their environmental impact the satisfaction felt by the working wives. Several studies have shown that job satisfaction is related to satisfaction in various aspects of life. Levy (2003), Arofani and Seniati (2007) stated that several aspects could affect job satisfaction, such as job characteristics, individual characteristics, role characteristics (role ambiguity) and role conflict, and excessive role burdens between family and work. Based on this background, researchers are interested in examining work-family conflicts, balancing 
strategies, and job satisfaction of wives in families with a husband and wives working based on the types of formal and informal job as well as based on the allocation of work time that has never been investigated by previous studies. The objectives of the study are: 1) identifying work-family conflicts, balancing strategies, and wives' job satisfaction; 2) analyzing differences in family characteristics based on the type of job and allocation of work time; 3) analyzing the effect of work-family conflict and balancing strategies on wives' job satisfaction in dual-earner families.

\section{Methods}

\section{Participants}

This research is part of research with the theme of work-family balance in dualearner families. The study used a cross-sectional study design conducted in the West Bogor District (Pasir Jaya and Menteng) and Central Bogor District (Panaragan and Paledang). The location selection made purposively considering that the area of West Bogor District was the district with the most population in Bogor City with 214.826 inhabitants while the Central Bogor District was the densest district in Bogor City with 12.564 inhabitants / $\mathrm{km}^{2}$ (BPS, 2011). Areas with high density were chosen as research locations so that there was a higher chance of getting samples that met the sampling frame given that there were no data on families with working wives according to a length of work. The population was dual-earner families that had children aged 0-9 years. Samples in this study are wives who work in the formal (IKF) or informal sector (IKNF)with working hours $\leq 8$ hours and $>8$ hours. The sampling technique used stratified non-proportional random sampling with a sample of 160 people.

\section{Measures}

Data collected includes sample and family characteristics, work-family conflict (work conflict affects family and family conflict affects work), balancing strategies, and job satisfaction (primary data). The instrument of work-family conflict is the adoption of a work-family conflict instrument (Netemeyer, Boles, \& McMurrian, 1996) with a Cronbach's alpha value of 0.790. The balancing strategy uses the Dual Employed Coping Scales (DECS) instrument (Skinner \& McCubbin, 1981), modified with a Cronbach's alpha value of 0.788 . The wives' job satisfaction uses the instrument of job characteristics and job satisfaction (Huang, 2011), modified with the Cronbach's alpha value of 0.900 . All three instruments use semantic data scales.

\section{Analysis}

Research data includes data on family characteristics, work-family conflict, balancing strategies, and wives' job satisfaction. Data quality management and control are done through coding, entry, cleaning, and editing data. Data analysis was performed descriptively and inferential statistics (multiple regression tests). 


\section{Findings}

\section{Family and Sample Characteristics}

The Independence T-Test result of sample and family characteristics is presented in Table 1. This study showed that more than two-thirds of the samples (64.4\%) were classified as small families, namely less than five people with an average of four family members. Nearly two-thirds of the sample's husbands $(62.5 \%)$ are in the early adult category, so are the four-fifths of the samples (81.2\%) who are in the early adult category of 18-40 years with an average value of 38,5 years and 34.9 years. Meanwhile, based on the length of marriage, more than one-third (36.3\%) of the samples had been married for 9-15 years with an average length of marriage 11.9 years.

During the education period, more than one-third of the sample's husbands were educated for 10-12 years (35.6\%) with an average of 11.28 years. As for the samples, almost one-third of the samples have studied more than 12 years $(32.5 \%)$, with an average of 11.3 years. Nearly one-third of samples (30.6\%) have worked for 2-5 years with an average length of work of 11.8 years. For the wives' income category, most of the samples obtained income ranging from Rp1.000.000 - Rp2.999.999, and the average wives' income was Rp2.085.231,25. The family welfare category measured by the poverty line $(\mathrm{GK})$, more than one-third of the sample families are categorized as not poor $(69.4 \%)$ with a total income per capita of more than $1.5 \mathrm{GK}$ (BPS, 2012).

Table 1. Different test of family characteristics

\begin{tabular}{|c|c|c|c|c|c|c|c|}
\hline \multirow[t]{2}{*}{ Characteristics } & \multicolumn{2}{|c|}{ Type of job } & value & \multicolumn{2}{|c|}{$\begin{array}{l}\text { Allocation of } \\
\text { working time }\end{array}$} & P-value & \multirow[t]{2}{*}{$\begin{array}{c}\text { Average } \\
\text { (Total) }\end{array}$} \\
\hline & IKF & IKNF & & $\leq 8$ & $>8$ & & \\
\hline Wives' age & 33.69 & 36.10 & $0.015 * *$ & 34.57 & 35.29 & 0.474 & 34.89 \\
\hline Husband's age & 36.36 & 40.63 & $0,000 * *$ & 38.32 & 38.71 & 0737 & 38.49 \\
\hline Age of the last child & 3.87 & 5.04 & $0.001 * *$ & 4.65 & 4.22 & 0.242 & 3.87 \\
\hline Family size & 3.79 & 4.72 & $0,000 * *$ & 4.28 & 4.22 & 0725 & 4.26 \\
\hline Wives' education & 13.95 & 8.65 & $0,000 * *$ & 10.66 & 12.08 & $0.017 *$ & $11: 30$ \\
\hline Husband's education & 13.45 & 9.10 & $0,000 * *$ & 10.78 & 11.88 & $0.045 *$ & 11.28 \\
\hline Length of work & 9.76 & 6.88 & $0.003 * *$ & $8: 30$ & 8.35 & 0.955 & 11.76 \\
\hline Length of marriage & 9.16 & 14.54 & $0,000 * *$ & 11.91 & 11.76 & 0880 & 11.86 \\
\hline $\begin{array}{l}\text { Wives' income } \\
\text { (Rp in thousand) }\end{array}$ & 2611.3 & 1559.1 & $0.003 * *$ & 1557 & 2371 & $0.002 * *$ & 2085.2 \\
\hline $\begin{array}{l}\text { Income per capita } \\
\text { (Rp in thousand) }\end{array}$ & 1529.2 & 791.9 & $0,000 * *$ & 910.9 & 14656 & $0.006 * *$ & 1160.5 \\
\hline
\end{tabular}

Different test results showed that the average husband's education, wives' education, wives' length of work, wives' income, income per capita and the number of assets owned by the wives who worked in the formal job (IKF) was higher than the wives who worked in the informal job (IKNF). However, the average for family size, husband's age, wives' age, length of marriage, and age of the last child was higher in the scores of families of IKF compared to families of IKNF.

Based on the wives' working hours, both wives who work $\leq 8$ hours and $>8$ hours on average belong to a small family of four family members. Wives who work $>8$ hours have higher education of wives and husbands than wives who work $\leq 8$ hours.

Wives working $>8$ hours have a higher average in husband's age, wives' age, husband's education, wives' education, wives' length of service, wives' income, income per capita, and total assets. As for the characteristics of family size, length of the 
marriage, and the age of the last child, the average is higher in families with wives who work $\leq 8$ hours compared to families with wives who work $>8$ hours.

The largest percentage of husbands work as private employees (30\%), as well as the largest percentage of IKF as private employees (23.1\%), while the largest percentage of IKNF are domestic servants (domestic workers) (26.9\%). Samples of those working $\leq 8$ hours were dominated by domestic servants $(38.6 \%)$, and those who worked $>8$ hours mostly worked as private employees (36.1\%). Most of the sample families have reached the stage of family development with school-age children (36.9\%) with an average age of the last child of the sample at 3-5 years old, and more than half the sex of the last child of the sample (58.8\%) is a girl.

\section{Work-Family Conflict}

Work-family conflicts include work conflicts affecting families and family conflicts affecting work. The instrument of work-family conflict is adopted in research (Netemeyer, Boles, and McMurrian 1996). The distribution of samples, according to work-family conflict, is presented in Table 2 . The sample has a score percentage of work-family conflict 43.7 percent. Work conflict affects the family $(47.1 \%)$ has a higher score than the score of family conflict affects work (40.2\%). IKF has a higher score (44.8\%) compared to IKNF (42.6\%). Whereas, based on working hours, samples with working hours $>8$ hours have a higher total score of work-family conflict $(46.2 \%)$ compared to samples with working hours $\leq 8$ hours (41.6\%).

\section{Balancing Strategy}

Data, according to the balancing strategy, is presented in Table 2. The highest balancing strategy score is found in the coping pattern of developing interpersonal relationships $(80.4 \%)$, while the sub variable with the lowest score is managing psychological tension and pressure (69.6\%). IKF has a score $(74.0 \%)$ higher than IKNF (72.7\%). Whereas, based on working hours, samples with working hours $>8$ hours have a higher score than samples with working hours $\leq 8$ hours.

\section{Wives' Job Satisfaction}

The achievement of wives' job satisfaction (Table 2) shows that overall, the achievement of job satisfaction per dimension was felt highest in the husband's support dimension (79.2\%) and lowest in the promotion dimension (64.5\%). According to the type of job, the achievement of job satisfaction of IKF (74.3\%) is higher than IKNF $(69.3 \%)$. Based on the wives' working hours, the achievement of wives' job satisfaction did not differ significantly between wives who worked $>8$ hours $(72.6 \%)$ and wives who worked $\leq 8$ hours $(71.8 \%)$.

Table 2 Percentage of work-family conflicts by type of job and working hours

\begin{tabular}{llrrrrr}
\hline \multirow{2}{*}{ No Statement } & \multicolumn{2}{c}{ Type of job } & \multicolumn{2}{c}{ Working hours } & \multirow{2}{*}{ Total } \\
\cline { 3 - 5 } & \multicolumn{2}{c}{ Formal } & Informal & $\leq 8$ & $>8$ & \\
\hline WORK-FAMILY CONFLICT & & & & & \\
\hline & Work conflict affects the family & 49.4 & 44.8 & 43.9 & 51.0 & 47.1 \\
1 & The demands of work & 50.5 & 42.3 & 41.8 & 51.9 & 46.4 \\
2 & Difficult to fulfill family responsibilities & 51.5 & 43.5 & 42.1 & 54.2 & 47.5 \\
3 & Unable to complete assignments at home & 53.5 & 49.5 & 49.3 & 38.2 & 51.5 \\
4 & Difficult to fulfill family duties & 40.0 & 41.3 & 38.2 & 43.6 & 40.6 \\
5 & Changes to the plans for family activities & 51.3 & 47.5 & 47.9 & 51.1 & 49.4 \\
\hline
\end{tabular}


Sunarti, Rizkillah, \& Muktiyah / Journal of Family Sciences, 2020, Vol. 05, No. 01

\begin{tabular}{|c|c|c|c|c|c|c|}
\hline \multirow[t]{2}{*}{ No } & \multirow[t]{2}{*}{ Statement } & \multicolumn{2}{|c|}{ Type of job } & \multicolumn{2}{|c|}{ Working hours } & \multirow[t]{2}{*}{ Total } \\
\hline & & Formal & Informal & $\leq 8$ & $>8$ & \\
\hline & Family conflicts affect work & 40.3 & 40.3 & 39.4 & 41.3 & 40.2 \\
\hline 6 & Family's demands & 40.8 & 40.8 & 40.9 & 40.6 & 40.8 \\
\hline 7 & Postpone doing things at work & 40.3 & 43.3 & 40.5 & 43.3 & 41.8 \\
\hline 8 & Cannot do work because of family demands & 42.0 & 42.3 & 41.6 & 42.8 & 42.1 \\
\hline 9 & Family life disrupts work's responsibilities & 37.8 & 33.5 & 33.2 & 38.6 & 35.6 \\
\hline 10 & $\begin{array}{l}\text { Tensions that occur in family interfere with } \\
\text { the ability to do work }\end{array}$ & 40.5 & 41.8 & 40.9 & 41.4 & 41.1 \\
\hline \multicolumn{2}{|r|}{ Total Work-Family Conflict } & 44.8 & 42.6 & 41.6 & 46.2 & 43.7 \\
\hline & BALANCE STRATEGY & & & & & \\
\hline 1 & $\begin{array}{l}\text { Maintaining, strengthening, and structuring } \\
\text { the family system }\end{array}$ & 75.4 & 70.5 & 71.7 & 74.8 & 73.1 \\
\hline 2 & Modifying working-family conditions & $76 . \varepsilon$ & $69 . \varepsilon$ & 71.8 & 75.1 & 73.3 \\
\hline 3 & Manage psychological tensions and stresses & $70 . c$ & 69.2 & 69.8 & 69.4 & 69.6 \\
\hline 4 & Perceptual control of lifestyle & 71.2 & $76 . C$ & 76.1 & 70.6 & 70.9 \\
\hline 5 & Develop interpersonal relationships & 83.7 & 77.2 & 79.0 & 82.1 & 80.4 \\
\hline \multicolumn{2}{|r|}{ Total Balancing Strategy } & $74 . \mathrm{C}$ & 72.7 & 71.7 & 73.1 & 72.3 \\
\hline \multirow{4}{*}{$\begin{array}{l}1 \\
2 \\
3\end{array}$} & WIVES JOB SATISFACTION & & & & & \\
\hline & Work is done at the workspace & 72.8 & 68.7 & 69.9 & 71.7 & 70.7 \\
\hline & Job promotion & 72.3 & 56.7 & 63.1 & 66.2 & 64.5 \\
\hline & $\begin{array}{l}\text { The attitude of superiors or people who are } \\
\text { more advanced in the field of work }\end{array}$ & 73.5 & 72.1 & 74.5 & 70.7 & 72.8 \\
\hline 4 & Salary received & 67.9 & 63.5 & 64.7 & 66.9 & 65.7 \\
\hline 5 & Co-worker ownership & 81.5 & 73.5 & 76.8 & 78.3 & 77.5 \\
\hline 6 & $\begin{array}{l}\text { Opportunities for developing knowledge and } \\
\text { skills }\end{array}$ & 73.9 & 63.5 & 69.1 & 68.2 & 68.7 \\
\hline 7 & Clarity of information at work & 68.5 & 69.7 & 69.1 & 69.1 & 69.1 \\
\hline 8 & Job motivation & 77.7 & 73.3 & 74.6 & 76.8 & 75.6 \\
\hline \multirow[t]{2}{*}{9} & Husband's support & 80.4 & 77.9 & 76.7 & 82.2 & 79.2 \\
\hline & Total job satisfaction & 74.3 & 69.3 & 71.1 & 72.6 & 71.8 \\
\hline
\end{tabular}

\section{Effects of Work-Family Conflict and Balancing Strategies on Wives' Job Satisfaction Based on Type of Job and Working Hours}

Multiple linear regression analysis on the model, as presented in Table 3, shows that IKF has an Adjusted R Square of 0.289 or 28.9 percent. This shows that the percentage of effect contribution of the independent variable (work-family conflict and the balancing strategy) to the dependent variable (wives' job satisfaction) is 28.9 percent, and the rest is effect by other variables not examined. In IKNF, the influence contribution of the independent variable (work-family conflict and the balancing strategy) to the dependent variable (wives' job satisfaction) was only 8.9 percent.

Table 3 The regression tests of work-family conflict and balancing strategies on wives' job satisfaction

\begin{tabular}{lcccccccr}
\hline \multirow{2}{*}{ Model } & \multicolumn{3}{c}{ Type of job } & \multicolumn{3}{c}{ Working hours } \\
\cline { 2 - 9 } & \multicolumn{2}{c}{ Formal } & \multicolumn{2}{c}{ Informal } & \multicolumn{1}{c}{$\leq 8$} & \multicolumn{1}{c}{ S } \\
\cline { 2 - 9 } & Beta & Sig, & Beta & Sig, & Beta & Sig, & Beta & Sig, \\
\hline A constant & & 0,000 & & 0,000 & & 0,000 & & 0.013 \\
Work-family conflict & $-0,393$ & 0,000 & $-0,218$ & 0.046 & $-0,323$ & 0.002 & $-0,265$ & 0.011 \\
Balancing Strategy & .369 & 0,000 & .258 & 0.019 & .293 & 0.004 & .451 & 0,000 \\
\hline F & 17,079 & 4,867 & 8,534 & 15,976 \\
Adjusted $R$ Square & .289 & \multicolumn{2}{c}{0.089} & .148 & .297 \\
\hline
\end{tabular}

Information: * significant at $\mathrm{p}$-value $<0.05$; ** very significant at $\mathrm{p}$-value $<0.001$ 
Based on working hours, the samples with working hours $\leq 8$ hours show that the variable work-family conflict and the balancing strategy contributed to the effect of wives' job satisfaction by 14.8 percent. Whereas in the sample with working hours of $>8$ hours, the contribution was higher at 29.7 percent. The considerable effect of workfamily conflict and the balancing strategy on job satisfaction is found in IKF and samples with working hours $>8$ hours.

\section{Effect of Work-Family Conflict and Balancing Strategies on Wives' Job Satisfaction}

The results show that in Model 1, the Adjusted R Square value was 0.222 or 22.2 percent. This shows that the percentage contribution of the influence of the independent variable (work-family conflict and the balancing strategy) to the dependent variable (wives' job satisfaction) is 22.2 percent. The independent variations used in the model (work-family conflict and balancing strategies) explain 22.2 percent of the dependent variable (wives' job satisfaction). In comparison, the remaining 76.8 percent is influenced by other variables not examined. The influence of work-family conflict and the balancing strategy on wives' job satisfaction is presented in Table 4.

\section{Effects of Work-Family Conflict, Balancing Strategies, Types of Work and Working Hours on Wives' Job Satisfaction}

The multiple linear regression analysis also shows that in Model 2, the Adjusted R Square value on the effect of work-family conflict, balancing strategies, type of job, and working hours on job satisfaction was 0.254 or 25.4 percent. This shows that the percentage of contribution of the influence of independent variables (work-family conflict, balancing strategies, type of job, and working hours) to the dependent variable (job satisfaction) is 25.4 percent.

The analysis showed that work-family conflict had a significant negative effect on wives' job satisfaction (Beta $=-0,324$ ). It means that the higher the work-family conflict experienced by the wives, the lower the wives' job satisfaction. The beta number shows that every increase of one standard deviation of family work conflicts will reduce job satisfaction by 0.324 standard deviation units. This is different from the balancing strategy, which has a significant positive effect on wives' job satisfaction. Beta value (0.325) on the balancing strategy shows that each increase of one unit of the balancing strategy carried out will increase job satisfaction by 0.325 units of standard deviation. On the type of job, there is a significant negative effect on wives' job satisfaction (Beta $=-0.190)$.

\section{Effects of Work-Family Conflict, Balancing Strategies, Types of Work, Working hours, and Sample Characteristics on Wives' Job Satisfaction}

The Model 3, multiple linear regression analysis in Table 4 shows that the Adjusted R Square on the effect of work-family conflict, balancing strategies, type of job, working hours, and sample characteristics on job satisfaction is 0.380 or 38 percent. This shows that the percentage effect contribution of the independent variable (work-family conflict, balancing strategy, type of job, working hours, and sample characteristics) to the dependent variable (job satisfaction) by 38 percent and the rest $(62 \%)$ is influenced by other variables not researched. Model 3 shows that workfamily conflict has a significant negative effect on wives' job satisfaction (Beta = - 
0.293). This means that the higher the work-family conflict experienced by the wives, the lower the job satisfaction of the wives.

On the balancing strategy, which has a significant positive effect on wives' job satisfaction, Beta value (0.238) shows that every increase of one unit of the balancing strategy carried out will increase job satisfaction by 0.238 standard deviation units. The sample characteristics that significantly influence the wives' job satisfaction are the wives' education and family income per capita. Wives education has a significant positive effect on wives' job satisfaction with Beta $=0.307$. This means that the longer the wives' education, the higher the wives' job satisfaction level. The beta number shows that every increase of one unit of the standard deviation of the wives' length of education will increase job satisfaction by 0.307 in the standard deviation unit. Other than that, income per capita, which is a combination, also has a significant positive effect on wives' job satisfaction. The higher the income per capita of the family, the higher the wives' job satisfaction $($ Beta $=0.169$ ). Beta value shows that every increase of one standard deviation of the old wives' education will increase job satisfaction by 0.169 standard deviation units.

\section{Effect of Work-Family Conflict Dimensions, Balancing Strategies, on Wives' Job Satisfaction}

The multiple linear regression analysis in model 4 shows that the value of Adjusted $\mathrm{R}$ Square on the effect of the dimensions of work-family conflict, and the balancing strategy on job satisfaction is 0.312 or 31.2 percent. This shows that the percentage contribution of the influence of the independent variable (dimensions of work-family conflict and balancing strategies) to the dependent variable (job satisfaction) by 31.2 percent and the rest (66.8\%) is influenced by other variables not examined. Multiple linear regression analysis, as presented in model 4 shows that the dimensions of work conflict affect the family significantly influences the job satisfaction of the wives where each increase of one standard deviation of work-family conflict will reduce job-family satisfaction by 0.214 in standard deviation units. However, the dimensions of family conflict affecting work are not significantly related to job satisfaction.

In the dimensions of balancing strategy variable, maintain, strengthen, and arrange the family system Beta value $=0.214$, where each 1 unit increase in the standard deviation of the dimensions will increase the wives' job satisfaction by 0.214 in the standard deviation unit. In the dimensions of controlling the meaning of lifestyle, perceptually, the value of Beta $=0.250$, each of which increases one unit standard deviation of these dimensions, will increase 0.250 job satisfaction in units of standard deviation. In comparison, the dimensions of developing interpersonal relationships show the value of Beta $=0.281$, which means that every increase of one standard deviation unit of the dimensions will increase the wives' job satisfaction by 0.281 in the standard deviation unit.

Table 4 The regression tests of independent variables on the dependent variable

\begin{tabular}{llcc}
\hline Variable & Beta & Sig, \\
\hline The regression tests of work-family conflict and balancing strategies on wives' job satisfaction & \\
\hline Model 1 & A constant & 0,000 \\
& Work-family conflict & $-0,296$ & $0,000 *$ \\
& Balancing Strategy & .379 & $0,000 *$ \\
\cline { 2 - 3 } & F & 23,076 \\
& Adjusted $R$ Square & .222 \\
\hline
\end{tabular}


The regression tests of work-family conflict, balancing strategies, types of job, and working hours on wives' job satisfaction

\begin{tabular}{llcc}
\hline Model 2 & A constant & & 0,000 \\
& Work-family conflict & $-0,324$ & 0,000 \\
Balancing Strategy & 0.325 & 0,000 \\
Type of job & $-0,190$ & 0.009 \\
Working hours & 0.068 & .338 \\
\hline F & \multicolumn{2}{c}{14,538} \\
Adjusted $R$ Square & 0.254 \\
\hline
\end{tabular}

The regression tests of work-family conflict, balancing strategies, family and sample characteristic on wives' job satisfaction

\begin{tabular}{|c|c|c|c|}
\hline \multirow[t]{12}{*}{ Model 3} & A constant & & 0.001 \\
\hline & Work-family conflict & -0.293 & 0,000 \\
\hline & Balancing Strategy & 0.238 & 0.001 \\
\hline & Type of job & 0.060 & 0.515 \\
\hline & Working hours & 0.005 & 0.939 \\
\hline & Wives' age & 0.125 & 0.102 \\
\hline & Wives' education & 0307 & 0.003 \\
\hline & Income per capita & 0.169 & 0.039 \\
\hline & Total assets & 0.006 & 0.928 \\
\hline & Long Working Wives & 0.123 & 0.111 \\
\hline & $\mathrm{F}$ & \multicolumn{2}{|c|}{11,550} \\
\hline & Adjusted R Square & \multicolumn{2}{|c|}{0.380} \\
\hline \multicolumn{4}{|c|}{$\begin{array}{l}\text { The regression tests of work-family conflict dimension and balancing strategies dimension on wives } \\
\text { job satisfaction }\end{array}$} \\
\hline \multirow[t]{12}{*}{ Model 4} & A constant & & 0,000 \\
\hline & Work-family conflict & & \\
\hline & - Work conflict affects the family & $-0,214$ & 0.005 \\
\hline & - Family conflicts affect work & $-10,110$ & 0.145 \\
\hline & Balancing Strategy & & \\
\hline & - Maintain, strengthen, and organize the family system & 0.214 & 0.006 \\
\hline & - Modifying working-family conditions & $-0,164$ & 0.034 \\
\hline & - Manage psychological tensions and stresses & 0.094 & 0.168 \\
\hline & - Controlling the meaning of lifestyle perceptually & 0.250 & 0,000 \\
\hline & - Develop interpersonal relationships & 0.281 & 0,000 \\
\hline & $\mathrm{F}$ & \multirow{2}{*}{\multicolumn{2}{|c|}{$\begin{array}{c}11,296 \\
0.312\end{array}$}} \\
\hline & Adjusted R Square & & \\
\hline
\end{tabular}

The regression tests of work-family conflict dimension, balancing strategies dimension, types of job, and working hours on wives' job satisfaction

\begin{tabular}{ccc}
\hline Model 5 & & 0,000 \\
& A constant & \\
Work-family conflict & -0.269 & 0,000 \\
- Work conflict affects the family & $-0,090$ & 0.219 \\
- Family conflicts affect work & & \\
Balancing Strategy & 0.206 & 0.006 \\
- Maintain, strengthen, and organize the family system & -0.207 & 0.007 \\
- Modifying working-family conditions & 0.098 & 0.136 \\
- Manage psychological tensions and stresses & 0.238 & 0,000 \\
- Controlling the meaning of lifestyle perceptually & 0.242 & 0.001 \\
- Develop interpersonal relationships & -0.216 & 0.002 \\
Type of job & 0.081 & 0.224 \\
Working hours & \multicolumn{2}{c}{10,775} \\
F & \multicolumn{2}{c}{0.356} \\
\hline Adjusted $R$ Square & \multicolumn{2}{c}{}
\end{tabular}

Information: * significant at $\mathrm{p}$-value $<0.05$; ** very significant at $\mathrm{p}$-value $<0.001$ 
Effect of Work-Family Conflict Dimension, Balancing Strategies Dimension, Type of job, and Working hours on wives' Job Satisfaction.

Multiple linear regression analysis, Table 4 shows that the Adjusted R Square value is 0.356 . This means that the independent variable (work-family conflict, balancing strategy, type of job, and wives' working hours) contributed an influence of 35.6 percent to the dependent variable (wives' job satisfaction), and the rest was influenced by other variables not examined. In the family work conflict variable and the balancing strategy, some dimensions have a significantly positive effect on wives' job satisfaction, such as maintaining, strengthening, and managing the family system; and controlling the meaning of lifestyle perceptually. This means getting more wives in carrying out a balancing strategy on the dimensions of maintaining, strengthening, and managing the family system, and perceptually controlling the meaning of lifestyle, the wives' job satisfaction will increase. While there are significant negative effects in work conflict affecting the family and modifying work-family conditions, if the wives experience work conflict more frequently affects the family and modifies work-family conditions, their job satisfaction will be lower. Model 5 also shows that there are also significant negative effects on the type of job to the wives' job satisfaction $(B=-0.216)$. Beta scores indicate that IKF has a greater influence on job satisfaction than IKNF.

\section{Effect of Work-Family Conflict Dimension, Balancing Strategies Dimension, Type} of job, Working hours, and Sample Characteristics on Wives' Job Satisfaction.

Based on the Model in Table 5, the Adjusted R Square value on the influence of the work-family conflict dimensions, the balancing strategy dimensions, the type of job, working hours, and the characteristics of job satisfaction by 0.427 or 42.7 percent. This means that the percentage contribution of the influence of the independent variable (work-family conflict dimensions, the balancing strategy dimensions, type of job, working hours, and characteristics) to the dependent variable (wives' job satisfaction) is 42.7 percent and the remaining $\mathbf{5 7 . 3}$ percent is influenced by the variable other.

Table 5 Effect of work-family conflict dimensions and balancing strategies, type of job, working hours, and characteristics on wives' job satisfaction

\begin{tabular}{|c|c|c|}
\hline Model & Beta & Sig \\
\hline A constant & & 0.001 \\
\hline \multicolumn{3}{|l|}{ Work-family conflict } \\
\hline - Work conflict affects the family & $-0,232$ & $0.002 * *$ \\
\hline - Family conflicts affect the work & $-0,097$ & 0.166 \\
\hline \multicolumn{3}{|l|}{ Balancing Strategy } \\
\hline - Maintain, strengthen, and organize the family system & 0.138 & 0.063 \\
\hline - $\quad$ Modifying working-family conditions & -0.147 & $0.049 *$ \\
\hline - $\quad$ Manage psychological tensions and stresses & 0.082 & 0.200 \\
\hline - Controlling the meaning of lifestyle perceptually & 0.152 & $0.025 *$ \\
\hline - Develop interpersonal relationships & 0.224 & $0.001 * *$ \\
\hline Type of job & 0.007 & 0.940 \\
\hline Working hours & 0.028 & 0.667 \\
\hline Wives' age & 0.080 & 0.289 \\
\hline Wives' education & 0.253 & $0.010 *$ \\
\hline Length of work & 0.093 & 0.223 \\
\hline Income per capita & 0.153 & $0.048 *$ \\
\hline $\mathrm{F}$ & \multicolumn{2}{|c|}{9,902} \\
\hline Adjusted R Square & \multicolumn{2}{|c|}{0.427} \\
\hline
\end{tabular}


Multiple linear regression analysis, as presented in Table 5 shows that work conflict affects the family negatively significant effect on wives' job satisfaction, where each increase of one unit of the standard deviation of work conflict affects the family. It will reduce job-family satisfaction by 0.232 in the standard deviation unit. Whereas in family conflicts affecting work, there is no significant effect on job satisfaction.

Regression analysis also shows that the dimensions of a balancing strategy that do not have a significant effect on job satisfaction are maintaining, strengthening and organizing the family system, and managing psychological tensions and pressures. Whereas, based on characteristics, only wives' education and income per capita have a significant positive effect on job satisfaction of wives, where the higher the education and income per capita, the better job satisfaction is felt by the sample.

\section{Discussion}

Work conflicts affect families have a higher score than scores of family conflicts that affect work. In line with Anafarta's research (2011), samples experienced more work-family conflict than family-work conflict. This can occur because the sample spends more time on work than the family, so the work problems are felt more. Apart from that, Greenhaus, Collins, and Shaw (2003) stated that psychological involvement in the family is higher than in work, so the sample is more satisfied with family life than work life. Based on the type of job, the samples in this study are divided into two sectors, namely formal and informal jobs. Samples with formal types of work have a higher score than samples with informal jobs. This is because 46.2 percent of IKF are employed as private employees, where the job has long working hours and inflexible work schedules. Long working hours can lead to higher stress (Elizabeth and Bischoff, 2005), and too many roles can lead to poor mental health (Glynn, Maclean, Forte, \& Cohen, 2009).

Based on working hours, for sample, those working for $>8$ hours have higher work-family conflict scores than those for working hours $\leq 8$ hours. Following research Greenhaus et al. (2003) stated that families who are more deeply involved in work than families have higher work-family conflict and higher stress while families who have higher family involvement than work have less work-family conflict and stress.

A balancing strategy must be undertaken by women to balance work and family life so that women can carry out their dual roles well and have a quality family. Skinner and Mc.Cubbin (1981) stated there is a structure of coping patterns carried out by families whose husbands and wives work, namely; (1) maintaining, strengthening, and managing the family system; (2) modifying working-family conditions; (3) managing psychological tensions and pressures; (4) controlling the perception of the meaning of life; and (5) developing interpersonal relationships and providing outside family support. IKF has a higher score than IKNF. That is because IKF has higher levels of education, income, and social support compared to IKNF so that access and ability to carry out a balancing strategy are better.

Whereas, based on working hours, samples with working hours $>8$ hours have a higher score than samples $\leq 8$ hours. This can happen because more samples that spend more time on work feel it is essential to carry out a balancing strategy so that all tasks and responsibilities can be fulfilled. This result is supported by research by Nasteruk and Garrison (2005), which stated that the higher the level of hassles experienced, the 
higher the coping strategy undertaken. Nevertheless, the sample with working hours less than equal to eight hours has a higher score than the sample with working hours more than eight hours on the coping pattern perceptually controlling the meaning of lifestyle. This can happen because 38.6 percent of the samples worked $\leq 8$ hours working as domestic servants. Hence, the samples belong to the middle and lower economic classes that tend to have a simple lifestyle that impacts on the ability to more perceptually control the meaning of lifestyle, in line with the results of Aprilia and Hartoyo (2014) which stated that low socioeconomic status has a low consumptive lifestyle.

The wives' job satisfaction is a condition that shows the feeling of satisfaction felt by the working wife for the work she is doing. Dimensions of job satisfaction are satisfied with work done, promotion, superiors' attitude or more advanced people in their fields, salary or wages received co-worker ownership, opportunities for knowledge and skill development, clarity of information, work motivation, and husband's support. Achievement of job satisfaction per dimension is felt highest in the dimensions of husband support and lowest in the dimensions of promotion or promotion. The results are in line with research conducted by Evans et al. (2010), which explains that careeroriented wives need more time in their work to get more help from their husbands in their work or household. The statement was supported by Deacon and Firebaugh (1988), who stated that the assistance provided by other parties (in this case, the husband) would help the wives in alleviating her role in the domestic and public sectors.

The low job satisfaction of the wives in the promotion dimension or increase in work compared to other dimensions is because most of the samples work as housemaids so that they do not need special skills and most of the samples work for 3-5 years, so they do not have enough experience in their work. This is consistent with the opinion expressed by Naveed et al. (2011), which reveals that the promotion of work in the workplace is determined by the length of work, ability, and skills of workers.

According to the type of job, the achievement of job satisfaction of IKF is higher than IKNF. This result is in line with the opinion expressed by Huang (2011), which stated that the workers in the formal sector, which in this case are dominated by whitecollar workers, have a higher level of intellect and knowledge than blue-collar workers who are more dominated by informal work. Knowledge and skills possessed by formal workers are assets in success at work that will have an impact on achieving job satisfaction. Based on the wives' working hours, the achievement of wives' job satisfaction does not differ significantly between wives who work $>8$ hours and wives who work $\leq 8$ hours. The difference in job satisfaction felt by wives working in the formal and informal sectors with working hours $\leq 8$ hours and $>8$ hours caused by differences in the characteristics of each sample. The difference in characteristics will then affect the job satisfaction felt by the wives.

Based on the results of wives who have a longer marriage time will be more satisfied at work compared to wives who are younger marriage age. The longer the wives' marriage allows the wives to adapt to carrying out their roles at work and family, the more quickly they can adapt to carrying out their roles. Besides, wives who get married longer generally have experience and are accustomed to carrying out their dual roles to make it easier for the wives to carry out their duties, which will ultimately result in better wives' job satisfaction. Besides, every time an increase in husband's education will increase the wives' job satisfaction. When the husband's education is getting better, the husband will provide more meaningful support for the work of his wives or family so that the wives will feel more helped in her work. This study is following research 
conducted by Evans et al. (2010), which explains that working husbands who have a higher education have better perceptions of working wives. This is because working wives can make specific contributions to the family and work, and the husband's support for the working wives is illustrated by the agreement between husband and wives in caring for and sharing family time.

This research shows that work-family conflict has a negative effect on job satisfaction. This means that the higher the conflict that the sample owns, the lower the job satisfaction that is owned. Namasivayam and Zhao (2006) research results and Anafarta (2011) also showed that work-family conflict has negative effects on job satisfaction. The results also showed that the better the wives did the balancing strategy, the higher the job satisfaction felt by the wives. This is following research conducted by Varatharaj and Vasantha (2012), which explains that the existence of work-family balance on working wives will increase efficiency, and ultimately the productivity of wives as workers and housewives will increase. This will further increase satisfaction in both work and family life.

The considerable influence of work-family conflict and the balancing strategy on job satisfaction is found in the samples with formal work types and working hours of more than eight hours. This is because 46.2 percent of the samples in the formal sector work as private employees that the type of job has low work flexibility resulting in high work-family conflict. Also, the high education, income, social support, and the number of assets owned by the sample in the formal sector make the sample have a better offsetting strategy. Whereas in the sample with work hours $>8$ hours, the effect of workfamily conflict and balancing strategies on wives' job satisfaction has a higher contribution than the sample with working hours $\leq 8$ hours because of the sample with work hours $>8$ hours have higher working hours, so it is easier to cause work-family conflicts. However, the sample of working hours $>8$ hours has a higher work-family balancing strategy because the sample has a higher level of education, income, and total assets compared to the sample of working hours $\leq 8$ hours. This affects the wives' higher job satisfaction on wives who work $>8$ hours.

The sample characteristics, which are significantly related to wives' job satisfaction, are wives' education and family income per capita. Albert and Davia (2005) explain that education is related to salaries or wages received by workers, which ultimately impacts the satisfaction felt by workers. Per capita income which is a combination, also has a significant positive effect on wives' job satisfaction. The higher income per capita a family, the more prosperous the family. These results indicate that the more prosperous the sample family, the more satisfied the sample.

The results show that the dimensions of work conflict affect the family significantly influence wives' job satisfaction. However, the dimensions of family conflict affecting work are not significantly related to job satisfaction. The result of work-family conflict has a negative effect on job satisfaction. This means that the higher the conflict in the sample, the lower the job satisfaction. The research results of Namasivayam and Zhao (2006) and (Anafarta, 2011) also show that work-family conflict has a negative relationship with job satisfaction.

The balancing strategy on the dimensions of maintaining, strengthening, and organizing the family system, controlling the meaning of lifestyle perceptually, and developing interpersonal relationships have a significant positive effect on wives' job satisfaction - the more samples of carrying out these strategies, the more samples of feeling satisfied. As stated by Haddock, Zimmerman, Ziemba, and Lyness (2006) where 
the way for families to do work-family balance is by flexible work scheduling, nontraditional work hours, doing work distribution, working at home, asking for support from superiors and colleagues work, and set strict limits on work. These things are very related to job satisfaction (Abrar \& Ghouri, 2010). Otherwise, the dimensions of workfamily have a significant negative effect on job satisfaction. This is because the samples tend not to do work-family modifications and do activities not based on planning and fixed use of time, as stated by Haddock, Zimmerman, Ziemba, and Lyness (2006), flexible work scheduling is the most prominent among families who have reportedly managed to balance work and family.

In the family work conflict variables and the balancing strategy, some dimensions have a significantly positive effect on wives' job satisfaction, such as Maintain, strengthen, and organize the family system, and Controlling the meaning of lifestyle perceptually. This means getting more wives in carrying out a balancing strategy on the dimensions of maintaining, strengthening, and managing the family system, and perceptually controlling the meaning of lifestyle, the wives' job satisfaction will increase. While there is a significant negative relationship in work conflict affecting the family and modifying work-family conditions, which means that if the wives experiences work conflict more frequently affects the family and modifies work-family conditions, the wives' job satisfaction will be lower.

Work conflict affects the family significantly negative effect on wives' job satisfaction. Whereas in family conflicts affecting work, there is no significant effect on job satisfaction. This is in line with Karatepe and Kilic's (2005) research, which stated that work conflict affects the family is a significant predictor of job satisfaction, whereas family conflict does not affect work.

\section{Conclusion and Recommendation}

\section{Conclusion}

Better income and education are owned by wives who work in formal rather than informal jobs and are better in wives who have an allocation of working hours more than eight hours than $\leq 8$ hours. The percentage of work conflict affects the family is higher than family conflict effects work. Wives who work in the formal job have a higher work-family conflict, balancing strategies, and job satisfaction than wives who work in the informal job. Whereas based on the allocation of working hours, wives who work $>8$ hours have a higher work-family conflict, balancing strategies, and job satisfaction than wives who work $\leq 8$ hours.

This study's results indicate that there are significant effects of the sub variable of family characteristics (length of marriage and husband's education) on job satisfaction felt by the wives. Work-family conflict has negative effects on wives' job satisfaction. In comparison, the balancing strategy has a positive effect on the wives' job satisfaction.

Based on the type of job, the effect of work-family conflict, and the balancing strategy on wives' job satisfaction has a higher contribution to IKF than IKNF. Whereas, based on working hours, the effect of work-family conflict and balancing strategies on wives' job satisfaction has a higher contribution to wives who work $>8$ hours than wives who work $\leq 8$ hours. 


\section{Recommendation}

Based on this study, researchers recommend to several parties: 1) the government is expected to provide family-friendly policies related to setting working hours, providing wages and compensation so that the wives can fulfill her duties as a worker and housewives; 2) related NGOs to conduct counseling related to the role of the wives in realizing time management and planning of suitable household activities; 3) families with husband and wives should make commitments related to household tasks in order to minimize work-family conflict: 4) future studies can further examine the relationship of job satisfaction with life satisfaction and include the husband as research respondents.

\section{References}

Albert, C., \& Davia, M. A. (2005). Education, wages, and job satisfaction. Proposal for the epunet 2005 conference. January 2005.

Anafarta, N. (2011). Relationship between work-family conflict and job satisfaction: a structural equation modeling (SEM) approach. International Journal of Business and Management, 6 (4), 168-177. Doi:10.5539/ijbm.v6n4p168

Aprilia, D., \& Hartoyo. (2014). Sociological analysis of student consumptive behavior. Journal of Sociology, 15 (1), 72-86.

Central Bureau of Statistics. (2012). Bogor in Numbers 2012. taken from https://bogorkota.bps.go.id/publication/2012/09/29/543a6f1d4034731f9adcaa51/k ota-bogor-dalam-angka-2012.html

Deacon, R. E., \& Firebough, F. M. (1988). Family Resource Management: Principles and Application (2nd Ed). USA: Allyn and Bacon Inc.

Elizabeth, M. O, \& Bischoff, L. G (2005). Balancing parenthood and academia: work/family stress and influenced by gender and tenure status. Journal of family, 26, 79. Doi: 10.1177 / 0192513 X04265942.

Evans C, et al. (2010). The Working Mother Report: What Mom Think. USA: Working Mother Media.

Glynn, K., Maclean H., Forte, T., \& Cohen, M. (2009). The Association between Role Overload and Women's Mental Health. Journal of Women's Health, 18 (2). Doi: 10.1089/jwh.2007.0783

Greenhaus, J. H, Collins, K. M, \& Shaw, J. D. (2003). The relation between workfamily balance and quality of life. Journal of Vocational Behavior, 63 Doi: 10.1016 / S0001-8791 (02) 00042-8.

Haddock, S. A, Zimmerman, T. S, Ziemba, S. J, \& Lyness, K. P. (2006). The practice of dual earner couples successfully balancing work and family. Journal of Family and Economic, 27 (2), 207-234. Doi: 10.1007/s10834-006-9014-y.

Hatta, J. H. (2011). The relationship between the source of work-family conflict and flexible work time allocation arrangements with the auditor's work performance. Accounting Research Media, 1(2).

Huang, T. P. (2011). Comparing motivating work characteristics, job satisfaction, and turnover intention of knowledge workers and blue collar workers, and testing a structural model of the variables relationship in China and Japan. The International Journal of Human Resource Management, 22 (4): 924-944. Doi : https://doi.org/10.1080/09585192.2011.555134 
Karatepe, \& Kilic. (2005). Relationships of supervisors support and conflicts in the work-family interface with the selected job outcomes of frontline employees. Journal of Tourism Management 28, 238-252. Doi: https://doi.org/10.1016/j.tourman.2005.12.019

Mccubbin, \& Skinner. (1981). Dual Employed Coping Scale. The University of Wisconsin Madison.

Maintier, C., Joulain, M., \& Floc'h, N. L. (2011). To what extent do attitudes to work and subjective dimensions of non-work contribute to men and women's life satisfaction in dual-earner pairs?. Women's Studies International Forum, 34, 242250.

Nesteruk, O., \& Garrison. (2005). An exploratory study of the relationship between family daily hassles and family coping and managing strategies. Family and Consumer Science Research Journal, 34, 140-154. Doi: 10.1177/1077727X05280667

Netemeyer, R. G, Boles, J. S, \& McMurrian, R. (1996). Development and validation of work-family conflicts and family-work conflict scales. Journal of Applied Psychology, 81, 400-410. Doi: https://doi.org/10.1037/0021-9010.81.4.400

Naveed, A., Usman, U., \& Busra, F. (2011). Promoting: a predictor of job satisfaction a study of glass industry oh Lahore (Pakistan). International Journal of Business and Social Science, 2(16), 301-305.

Rathaktishnan, B. (2011). Job satisfaction among white-collar and blue-collar female workers in Sabah. International Conference on Management (ICM 2011) Proceeding: University Malaysia Sabah.

Joner, S., \& Wankel, C. (1986). Third Edition Management. Jakarta(ID): CV. Intermedia.

Tambingon, H. N. (1999). Search for childcare based on gender in the family of working and non-working mothers and its relation to the nutritional status of children under five. [thesis]. Bogor (ID): Bogor Agricultural University.

Varatharaj, V., \& Vasantha, S. (2012). Work-life balance a source of job satisfaction-an exploratory study on the view of women employees in the service sector. International Journal of Multidisciplinary Research, 2(3), 450-458. ISSN 2231 5780 